IRSH 50 (2005), Supplement, pp. 93-I 22 DOI: I0.1017/S0020859005002087

(C) 2005 Internationaal Instituut voor Sociale Geschiedenis

\title{
Pyrenean Marriage Strategies in the Nineteenth Century: The French Basque Case
}

\author{
MARIE-PIERRE ARRIZABALAGA
}

Summary: Marriage strategies in the rural Basque country of the nineteenth century differed according to social background and gender. Propertied families had more diversified strategies than landless families as a result of persistent single inheritance practices, population growth, urbanization, and industrialization which generated massive emigration. Propertied families helped some of their children to settle in local rural villages and others to emigrate to cities (women) or to America (men). Landless families, by contrast, continued to settle most of their children in local rural villages, others emigrating to America only later in the century, avoiding the cities at all cost. Men, no matter their social background, benefited the most from new economic opportunities because most of them married into families of equal or higher status. Women, by contrast, did not have equal opportunities because few married upward and outside their professional group. When women did not marry within their socio-professional group or remain single, they married into families of lower status (more often than men).

Through population statistics, historians and demographers have long observed and quantified the rural exodus and the massive emigration movements which the Pyrenees and France as a whole experienced in the nineteenth century. They used macro-structural arguments to justify the new demographic trends, blaming them on rural overpopulation, rural impoverishment, industrialization, and urbanization. ${ }^{\mathrm{I}}$ In this period, the Pyrenees did indeed experience massive emigration due to unprecedented demographic growth. Communities could not absorb the excess population as a result of their limited economic resources and their predominantly small-landowning agricultural activities. Further, land

I. On the demography of the Pyrenees, see G. Callon, "Le mouvement de la population dans le département des Basses-Pyrénées au cours de la période I82I-I920 et depuis la fin de cette période", Bulletin de la société des sciences, lettres et arts de Pau, 53 (1930), pp. 8 I-I I3; Michel Chevalier, La Vie humaine dans les Pyrénées ariégeoises (Paris, 1956); André Etchelecou, Transition démographique et système coutumier dans les Pyrénées occidentales (Paris, 1991); Théodore Lefebvre, Les Modes de vie dans les Pyrénées-Atlantiques orientales (Paris, 1933); Jacques Saint-Macary, La Désertion de la terre en Béarn et dans le Pays Basque (Pau, France, I939). 
partition imposed by the Civil Code risked impoverishing the entire population and ruining the region's economy. Ultimately, industrial activities in local towns and regional cities offered new resources and attractive opportunities for this excess population to find jobs to support themselves and their families.

Besides these macro-structural arguments, there were other issues at stake which explain the demographic evolution of the Pyrenees and massive emigration in the period. Historians and anthropologists have justified these patterns using micro-longitudinal methods to demonstrate how France's new egalitarian inheritance laws, those of the Civil Code of I 804, actually destabilized ancient customs and generated new behaviour. In order to perpetuate their ancient single inheritance practices and preserve their traditional "house system", ${ }^{2}$ Pyrenean families elaborated new strategies which bypassed the new laws and excluded numerous cadets or "non-inheriting children" from land succession, forcing them to depart from the countryside to cities or overseas. ${ }^{3}$ Rural depopulation and emigration were particularly observable in the traditional inegalitarian provinces south of the Loire River. ${ }^{4}$ Conversely, provinces north of the Loire River, such as Brittany, were affected in later periods as a result of their traditional practices of egalitarian succession and land partition. ${ }^{5}$

Overpopulation, impoverishment, and the egalitarian laws of the Civil

2. The "house system" in the Pyrenees is a system which all propertied families respected and upon which they all depended. Families were recognized as household units comprising individuals with different roles and status, cohabiting in one house, all descending from the same family. The house was to be transmitted intact from one generation to the next and was the guarantor of family succession, lineage, and continuity. Family culture imposed these traditional values for the survival of the house so much so that the interests of the house prevailed over those of individuals. The Civil Code threatened these old traditional values, and therefore the integrity of the house, because it protected individual rights over property rights by imposing equal inheritance or the equal partition of land between siblings. As a result of partition, the house could no longer support a three-generational family living together (the stem family). The family business might then go bankrupt and successors be forced to sell the house. To avoid such tragedy, families had to circumvent the new law to maintain single inheritance and thus protect the house system.

3. Georges Ravis-Giordano and Martine Segalen (eds), Les Cadets (Paris, 1994), and Gérard Bouchard, John Dickinson, and Joseph Goy (eds), Les Exclus de la terre en France et au Quebec (XVIIe-XXe siècles) (Paris, I998).

4. Rolande Bonnain, Gérard Bouchard, and Joseph Goy (eds), Transmettre, hériter, succéder. La reproduction familiale en milieu rural, France-Quebec, XVIIIe-XXe siècles (Paris, I992), and D. Comas d'Argemir and J-F. Soulet (eds), La familía als Pirineus (Andorra, I993). In addition, see works by: Isaac Chiva and Joseph Goy (eds), Les Baronnies des Pyrénées. Maisons, mode de vie, société, vol. I (Paris, I98I) and Les Baronnies des Pyrénées. Maisons, espace, famille, vol. 2 (Paris, 1986); Alain Collomp, La Maison du père. Famille et village en Haute-Provence aux XVIIe et XVIIIe siècles (Paris, I983); Bernard Derouet, "Pratiques successorales et rapport à la terre: les sociétés paysannes d'Ancien Régime”, Annales ESC, I (1989), pp. I73-206.

5. For publications on inheritance systems north of the Loire River, see Martine Segalen, Quinze générations de Bas-Bretons. Parenté et Société dans le Pays Bigouden Sud, I720-1980 
Code do help to explain why France, and the Pyrenees in particular, experienced rural depopulation and massive emigration in the nineteenth century, but only partially. The phenomenon, however, is more complex and we will here propose additional explanations. Using the Basque country as a case study and family reconstitution as a method, it appears that in this period rich and poor families from rural backgrounds all had difficulty in settling their children in the village. This was due to larger family sizes (of three or four children on average). It became an issue particularly for landed Pyrenean families who could settle only two (perhaps three) of their children comfortably in the village or nearby, marrying them into families of equal status. The other children, however, could not hope for homogamous marriages and a comfortable life because local options were limited. Settlement in their village environment, especially for women, often meant resorting to socially downward marriages or a life of subordination as unmarried "servants" in the family house.

From the mid-nineteenth century onwards, however, non-inheriting men and women from a rural agricultural background chose other destinies and destinations. Some (especially women) opted for urban migration (to the local towns, the regional cities of Bayonne and Pau, and also to Bordeaux and Paris) and others (especially men) for overseas emigration (to Argentina and Uruguay in South America, to Newfoundland and New Orleans, and later to Central America, the western states of the United States, and Canada around the turn of the century $)^{6}$ where, as a result of massive industrialism and greater employment opportunities, they had better chances of a decent life (see Table I). Urban and overseas emigration thus became options which attracted many men and women from a rural background in the Pyrenees. ${ }^{7}$ Departure was a strategy to avoid poor destinies, downward marriages, or life-long service labour as unmarried men and women.

(Paris, 1985); Gérard Béaur, "Land Transmission and Inheritance Practices in France During the Ancien Régime: Differences of Degree or Kind?”, in David R. Green and Alistair Owens, Family Welfare: Gender, Property, and Inheritance since the Seventeenth Century (London, 2004), pp. $3 \mathrm{I}-46$.

6. On Basque emigration to America in the nineteenth and twentieth centuries, see William A. Douglass and Jon Bilbao, Amerikanuak: Basques in the New World (Reno, NE, 1975).

7. On Basque migration, see articles by Marie-Pierre Arrizabalaga: "Réseaux et choix migratoires au Pays Basque. L'exemple de Sare au XIXe siècle”, Annales de démographie historique, (1996), pp. 423-446; "Comment le marché de l'emploi national et international a-t-il influencé les destins individuels au sein de familles basques et les modalités de transmission du patrimoine au XIX siècle?”, in Christian Dessureault, John Dickinson, and Joseph Goy (eds), Famille et marché (XVIe-XXe siècles) (Sillery, Québec, 2003), pp. I83-I98; "Migrations féminines - migrations masculines: des comportements différenciés au sein des familles basques au XIXe siècle”, in Luigi Lorenzetti, Anne-Lise Head-König, and Joseph Goy (eds), Marchés, migrations et logiques familiales dans les espaces français, canadien et suisse, $X V I I I^{e}-X X^{e}$ siècles (Berne, 2005), pp. I83-195. 
Table I. Migration among the children and grandchildren of the 120 couples in the sample: second-and third-generation cohorts

\begin{tabular}{|c|c|c|c|c|c|c|c|c|}
\hline \multirow[t]{2}{*}{ Residence } & \multicolumn{2}{|c|}{ Children } & \multicolumn{2}{|c|}{ Total } & \multicolumn{2}{|c|}{ Grandchildren } & \multicolumn{2}{|c|}{ Total } \\
\hline & Men & Women & $\mathrm{N}$ & $\%$ & Men & Women & $\mathrm{N}$ & $\%$ \\
\hline Rural & 118 & 162 & 280 & $(61.5)$ & 153 & 188 & 341 & $(42.4)$ \\
\hline Urban & 21 & 29 & 50 & (11.0) & 41 & 77 & 118 & (14.7) \\
\hline Abroad & 36 & 20 & 56 & $(12.3)$ & 96 & 43 & 139 & $(17.3)$ \\
\hline Unknown & 40 & 29 & 69 & $(15.2)$ & 124 & 82 & 206 & $(25.6)$ \\
\hline Total & 215 & 240 & 455 & $(100)$ & 414 & 390 & 804 & $(100)$ \\
\hline
\end{tabular}

Contrary to what the historiography has argued, emigration affected rich as well as poor families. More remarkably, the data on the Basque country show that, actually, men and women from richer families departed earlier and in greater number than those from poorer families. Poverty therefore is not a strong argument to explain rural depopulation and massive emigration in the Pyrenees in the nineteenth century. ${ }^{8}$ Nor does it explain the destinies and destinations of emigrants.

Through an analysis of marriage strategies among rural Basque men and women of different socio-economic and professional backgrounds in the nineteenth century, we will attempt to explain these discernible behaviours, analysing the role which marriage opportunities played in explaining why some settled in their rural environment and others departed from it permanently. Did women from propertied or landless families have the same chance as men when it came to marrying into families of equal or higher social status, and if so why? Could women's marriage opportunities in the village explain their different socioprofessional and migration destinies compared with men? Could the study of marriage patterns then give more complete and refined explanations for women's preference for urban migration and men's preference for overseas emigration?

\section{METHODOLOGY}

The Basque country in the western Pyrenees will here be used as a case study in the analysis of marriage strategies in an attempt to understand better the rural depopulation and the massive emigration phenomena which the Pyrenees experienced in the nineteenth century. In addition, family reconstitution will provide the data and illustrations to justify the greater

8. Historians specialized in inheritance and emigration in the Pyrenees in the nineteenth century have argued this, especially Antoinette Fauve-Chamoux and Rolande Bonnain. See also Gérard 
diversity of marriage strategies and migration destinies among the richer families of the communities compared with the poorer ones. Finally, analysis of the data will help to explain the attraction of women to cities and that of men to America. For that purpose, we reconstituted I 20 genealogies, 20 from each of the six villages selected as part of this sample study: 4 highland villages (Sare, Aldudes, Mendive, Alçay) and 2 lowland villages (Isturits and Amendeuix) scattered across the 3 French Basque provinces and remote from the regional, coastal city of Bayonne (Figure I overleaf). ${ }^{9}$

Our genealogical research began with the selection of $\mathrm{I} 20$ couples who married during the first two decades of the nineteenth century, the reconstitution of their life experiences, as well as those of their children (second-generation cohort) who married between I830 and I860, and finally those of their grandchildren (third-generation cohort) who married after I 860: a three-generational family reconstitution which involved nearly 3,000 individuals from the early nineteenth century almost until today. To complete these genealogies, we consulted the civil registers (records of births, marriages, and deaths) of the 6 villages and of all neighbouring villages (within a 20-mile radius) over a period of 200 years. ${ }^{10}$ The purpose of this regional research work was to reconstitute the destinies of the 120 original couples and all their descendants (children, grandchildren, and their respective spouses) who lived in their village of birth or elsewhere in the département, in neighbouring or distant villages, local towns, distant towns, or in the regional cities of Bayonne and Pau (see Table I).

We also cross-analysed the genealogies with the land registers (cadastre), the succession registers (enregistrement) and the notarial records (notaire), which provided additional information on ownership, property size,

Bouchard, Joseph Goy, and Anne-Lise Head-König (eds), Problèmes de la transmission des exploitations agricoles (XVIIIe-XXe siècles) (Rome, 1998); Anne-Lise Head-König, Luigi Lorenzetti, and Béatrice Veyrassat (eds), Famille, parenté et réseaux en Occident (XVIIe-XXe siècles) (Geneva, 200I).

9. The French Basque country is located in the most western part of the Pyrenees between the Atlantic Ocean in the west and Béarn in the east in the French département of PyrénéesAtlantiques, and between Spain in the south and the French département of Landes in the north. The country is divided into three provinces: Labourd, Basse-Navarre, and Soule (from west to east). The six villages are: Sare, a highland village in Labourd; Aldudes and Mendive, two highland villages in Basse-Navarre; Alçay, a highland village in Soule; and Isturits and Amendeuix, two lowland villages in Basse-Navarre. The regional capital city is Bayonne, a port city on the Atlantic Ocean. These isolated villages were deliberately selected away from Bayonne in order to make sure that the nearby regional city did not constitute a natural magnet to the excess rural population. As a result of the distances involved, people from isolated villages then had a wider variety of migration options.

I0. Because some of the I 20 couples' grandchildren, born in the late I 890 or or early I 900 , lived long lives and died in the I980s or I990s, we systematically consulted the civil registers of the 6 villages and of all the i 5-20 neighbouring villages from i 800 until the present. 


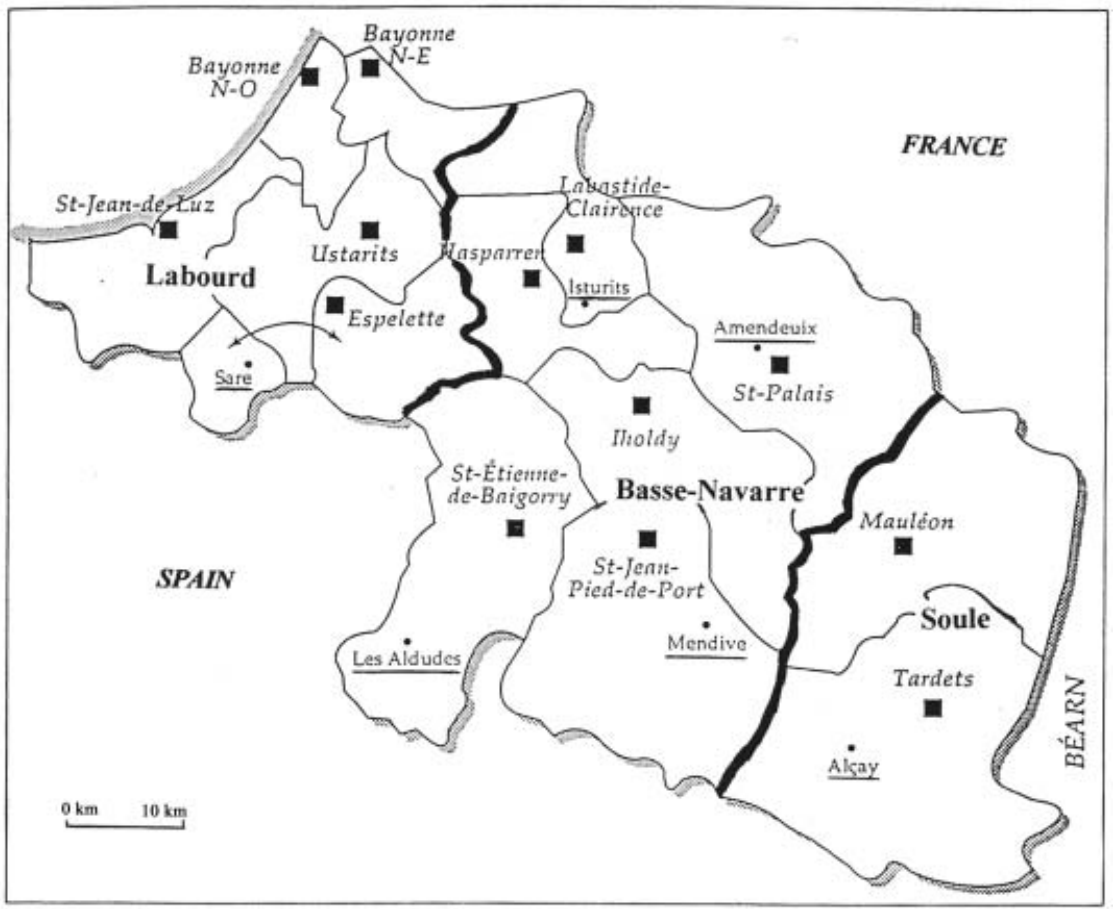

Figure I. Location of the six villages in the French Basque country in the western Pyrenees.

dowries, and inheritance. ${ }^{\mathrm{II}}$ We proceeded to computerize the data, entering all available information by cohort: the $\mathrm{I} 20$ original couples (the first-generation cohort), their children (the second-generation cohort), and their grandchildren (the third-generation cohort). This multi-generational categorization subsequently provided material for an analysis of marriage strategies and their evolution.

The French Basque country being mainly a region of small farm ownership, we selected families who were representative of that population. As a result, 65 per cent of the $\mathrm{I} 20$ original couples in the early I $800 \mathrm{~s}$ were propertied farmers or artisan farmers and 35 per cent landless farmers or artisan farmers. Family reconstitution showed that these i 20 couples (first generation) had 567 children ( 4.7 children per couple), all born in the first half of the nineteenth century: 456 survived until adulthood (3.8 children per family). ${ }^{\mathrm{I} 2}$ The surviving second-generation cohort in turn had

I I. This was the only way to study migration, because the nineteenth-century census data for all Basque villages were destroyed in two successive fires in the archives of Bayonne and Pau in the early twentieth century.

I 2. Children who died before the age of 2 I were regarded as never having reached adulthood. A total of I I I of the 567 second-generation children (19.6 per cent of the cohort) and 230 of the I,039 third-generation children (22.I per cent of the cohort) died before reaching $2 \mathrm{I}$. 
Table 2. Marital status of the children and grandchildren of the I20 couples in the sample: second-and third-generation cohorts

\begin{tabular}{|c|c|c|c|c|c|c|c|c|}
\hline \multirow{2}{*}{$\begin{array}{l}\text { Marital } \\
\text { status }\end{array}$} & \multicolumn{2}{|c|}{ Children } & \multicolumn{2}{|c|}{ Total } & \multicolumn{2}{|c|}{ Grandchildren } & \multicolumn{2}{|c|}{ Total } \\
\hline & Men & Women & $\mathrm{N}$ & $\%$ & Men & Women & $\mathrm{N}$ & $\%$ \\
\hline Married & 109 & 159 & 268 & $(58.8)$ & 127 & 198 & 325 & $(40.2)$ \\
\hline Unmarried & 42 & 48 & 90 & (19.7) & 78 & 76 & 154 & $(19.0)$ \\
\hline Unknown & 64 & 34 & 98 & $(21.5)$ & 213 & 117 & 330 & $(40.8)$ \\
\hline Total & 215 & 241 & 456 & $(100)$ & 418 & 391 & 809 & $(100)$ \\
\hline
\end{tabular}

I,039 children ( 3.9 children per family), all born after I 840: 809 survived until adulthood ( 3 children per family). Of the 456 surviving secondgeneration children, 268 ( 58.8 per cent) married, and of the 809 surviving third-generation children 325 (40.2 per cent) married. ${ }^{13}$ The focus of this study will be on these married individuals and their spouses (see Table 2).

It is important to note that, of the unknown cases, many were men and women who had emigrated to America or to cities, where a number remained single. We know more about women's marriage destinies than men's because women were less inclined than men to emigrate abroad, and therefore many women were located in villages, local towns, and regional cities. ${ }^{\text {I4 }}$

When computerizing the data, we created various socio-professional categories for all individuals and their parents. If they were married, we did the same for their spouses and their spouses' parents. These variables included information on their profession, property ownership, the size of their property, and their status. We also included a special category which combined all aspects, socio-economic and professional, along the lines of the HISCLASS classification. ${ }^{\mathrm{Is}}$ Each individual, no matter what their

I 3. We were unable to locate the marriage certificates of all married descendants, especially those of emigrants who married in America or in large cities such as Bordeaux or Paris. As a consequence, our data suggest that only 40.2 per cent of the third-generation cohort married. It is likely that more of them actually married, but we were unable to reconstitute their lives, let alone their backgrounds. Nonetheless, many of this third-generation cohort probably remained single. I4. Women did not emigrate as much as men. Indeed, among the second- and third-generation cohorts, 67.5 per cent and 48.2 per cent of women respectively never left their rural environment, compared with 54.9 per cent and 37 per cent respectively for men (see Table 2). As a consequence, women's destinies were reconstituted in greater details than men's.

I 5. HISCLASS: a standard social-class scheme based on the Historical International Standard Classification of Occupations (HISCO). See the introduction to the present volume. The HISCLASS classification runs from I to I 2: I and 2 referring to higher managers and higher professionals; 3,4 , and 5 to lower managers, lower professionals, clerical and sales personnel, and lower clerical and lower sales personnel; 6 and 7 to foremen and propertied medium-skilled workers; 8 to propertied farmers; 9 to landless lower-skilled workers; Io and I 2 to landless lower-skilled farm workers and unskilled farm workers; and I to unskilled workers. These have been restructured to form seven categories in the tables. 
marital status, was assigned a "class" category, as were his or her parents. For comparative purposes, we assigned a "class" variable to all individuals' spouses and their parents. We were able to do so as a result of the crossanalysis of the various succession sources (land and succession registers). The purpose of creating such variables was to compare the socioprofessional backgrounds of the parents and parents-in-law of married individuals within each cohort and between cohorts. ${ }^{16}$ This analysis will then lead to an in-depth study of the evolution of the marriage patterns of men and women and of homogamy in the nineteenth century. Was there indeed a gender and socio-professional differentiation in marriage strategies which explains the different migration destinies of Basque men and women?

\section{HOMOGAMY: THE DATA}

The analysis of the three-generational computerized data on the married couples within each cohort clearly highlights the fact that, throughout the nineteenth century, the great majority of them married within their socio-professional group and subsequently enjoyed the same status as their parents. Indeed, of the men and women of the first-, second-, and third-generation cohorts who married - those who married in the early, mid-, and late nineteenth century respectively - the large majority had the same socio-professional background as their spouses, with their respective parents having the same profession and living within the same social environment (see Tables 3 and 4 ). ${ }^{17}$ Indeed, the data indicate that throughout the nineteenth century 60 to 70 per cent of the married children in the sample married within their socio-professional group, choosing a spouse whose parents had the same socio-professional background as their own parents (see Tables 3 and 4 ).

When comparing men and women, however, it appears that men had greater chances of marrying a person within their socio-professional group than women: 65.7 to 74 per cent for men throughout the century compared with 60.8 to 68.9 per cent for women. Despite these gender differences, it is clear that, whenever possible, propertied or landless families ensured that

16. We were able to collect an extensive amount of information on the marriages of those who had settled in the local towns and the regional cities of Bayonne and Pau because we systematically consulted their registers from i 830 to 1950 . We could not do the same for those who emigrated to America. Nevertheless, information on them was sometimes available in land and succession registers. Hence the number of unknown.

17. It is important to note that, for the purpose of our analysis, we disregarded all "unknown cases", individuals whose destinies were cases partially available or missing. Indeed, we sometimes know that specific individuals married, but we were either unable to collect information on the origins of their spouse or the data did not provide information on their inlaws. 
Table 3. Intergenerational mobility of married men: comparing the socioprofessional status of their fathers and fathers-in-law, for first-, second-and third-generation cohorts (the original first-generation grooms, their sons, and their grandsons)

Intergenerational mobility First generation Second generation Third generation

\begin{tabular}{llll}
\hline Upward marriages & $16.2 \%$ & $14.3 \%$ & $14.4 \%$ \\
Homogamy & $65.7 \%$ & $74.0 \%$ & $69.9 \%$ \\
Downward marriages & $18.1 \%$ & $11.7 \%$ & $15.7 \%$
\end{tabular}

Note: We considered ros of the I 20 first-generation husbands; 77 of the rog secondgeneration husbands (sons); and 83 of the 127 third-generation husbands (grandsons). We excluded all cases which provided no or partial information on in-laws.

Table 4. Intergenerational mobility of married women: comparing the socio-professional status of their fathers and fathers-in-law, for first-, second-and third-generation cohorts (the original first-generation brides, their danghters and their granddanghters)

Intergenerational mobility First generation Second generation Third generation

\begin{tabular}{llll}
\hline Upward marriages & $18.1 \%$ & $20.6 \%$ & $13.6 \%$ \\
Homogamy & $65.7 \%$ & $60.8 \%$ & $68.9 \%$ \\
Downward marriages & $16.2 \%$ & $18.6 \%$ & $17.5 \%$
\end{tabular}

Note: We considered Ios of the I 20 first-generation wives; 102 of the I 59 secondgeneration wives (daughters); and 132 of the 198 third-generation wives (granddaughters). We excluded all cases which provided no or partial information on in-laws.

most of their children married into their own socio-professional group, in the rural environment with which they were familiar. What do family reconstitutions say additionally about these particular couples?

Family reconstitutions show that among propertied families (artisans, artisan farmers, and farmers) (categories 6, 7, and 8), the men and women who generally married within their own socio-professional group were mainly the heirs or heiresses to the family assets, one per family, who would take over the family farm or craft business of their parents, who lived and worked with them as stem families, ${ }^{18}$ and who therefore enjoyed the same socio-professional status as their parents and in-laws (see Tables 5 to 9). The selected child, male or female, was in charge of perpetuating single-inheritance traditions to protect the ancient "house system", maintaining the family property undivided, and transmitting it intact to

I8. Besides Frederick Le Play's works, see more recent contributions on the matter by Antoinette Fauve-Chamoux and Emiko Ochiai (eds), Maison et famille souche: perspectives eurasiennes (Kyoto, 1998). 
Table 5. Socio-professional status of husbands' fathers, compared with that of their in-laws: first-generation cohort (the couples in the sample, who married between I 800 and I 820 )

\begin{tabular}{llllllll}
\hline Status of husbands' fathers (down) and & $1+2$ & $3,4,5$ & $6+7$ & 8 & 9 & 11 & $10+12$
\end{tabular} in-laws (across), by category

1+2 Higher managers and professionals

3,4,5 Lower managers and professionals, clerical and sales

$6+7 \quad$ Skilled workers

$8 \quad$ Farmers and fishermen

$9 \quad$ Lower-skilled workers

11 Unskilled workers

10+12 Farm workers

0 2

0 1

$\begin{array}{lll}0 & 1 & 1\end{array}$

$\begin{array}{llll}4 & 57 & 1 & 12\end{array}$

$\begin{array}{llr}1 & 0 & 1\end{array}$

$1-11$

Table 6. Socio-professional status of husbands' fathers, compared with that of their in-laws: second-generation cohort (the sons of the I20 couples in the sample, who married between I 830 and I860)

\begin{tabular}{|c|c|c|c|c|c|c|c|c|}
\hline \multicolumn{2}{|c|}{$\begin{array}{l}\text { Status of husbands' fathers (down) and } \\
\text { in-laws (across), by category }\end{array}$} & $1+2$ & $3,4,5$ & $6+7$ & 8 & 9 & 11 & $10+12$ \\
\hline $1+2$ & $\begin{array}{l}\text { Higher managers and } \\
\text { professionals }\end{array}$ & 0 & & & & & & \\
\hline $3,4,5$ & $\begin{array}{l}\text { Lower managers and } \\
\text { professionals, clerical and sales }\end{array}$ & & 0 & & & & & \\
\hline $6+7$ & Skilled workers & & & 0 & 1 & & 1 & \\
\hline 8 & Farmers and fishermen & & 2 & 3 & 46 & 2 & 1 & \\
\hline 9 & Lower-skilled workers & & & 1 & & 0 & 4 & \\
\hline 11 & Unskilled workers & & & & & & 0 & \\
\hline $10+12$ & Farm workers & & & & 3 & 2 & & 11 \\
\hline
\end{tabular}

the next generation. The single heir was traditionally the first-born male or female child (aînesse intégrale), who would marry the non-inheriting son or daughter of a propertied family of similar background. The couple would then settle in the heir's family house as stem families.

In the nineteenth century, however, Basque families adapted their inheritance strategies to the new demographic and economic conditions, allowing their sons to emigrate in greater number than their daughters. As a result, they often opted for female inheritance, selecting their heirs from among their first-born or cadet daughters. ${ }^{19}$ In addition, one or two of the siblings (male or female) of the heir or heiress experienced something

19. On the matter of Pyrenean single inheritance strategies (the Basque case included) in comparison with Asia, see Emiko Ochiai (ed.), The Logic of Female Succession: Rethinking Patriarchy and Patrilineality in Global and Historical Perspective (Kyoto, 2003). See too Rose 
Table 7. Socio-professional status of wives' fathers, compared with that of their in-laws: second-generation cohort (the daughters of the I2O couples in the sample, who married between I 830 and I860)

\begin{tabular}{|c|c|c|c|c|c|c|c|c|}
\hline \multicolumn{2}{|c|}{$\begin{array}{l}\text { Status of wives' fathers (down) and in- } \\
\text { laws (across), by category }\end{array}$} & \multirow{2}{*}{$\frac{1+2}{0}$} & \multirow[t]{2}{*}{$3,4,5$} & \multirow[t]{2}{*}{$6+7$} & \multirow[t]{2}{*}{8} & \multirow[t]{2}{*}{9} & \multirow[t]{2}{*}{11} & \multirow[t]{2}{*}{$10+12$} \\
\hline $1+2$ & $\begin{array}{l}\text { Higher managers and } \\
\text { professionals }\end{array}$ & & & & & & & \\
\hline $3,4,5$ & $\begin{array}{l}\text { Lower managers and } \\
\text { professionals, clerical and sales }\end{array}$ & & 0 & & & & & \\
\hline $6+7$ & Skilled workers & & & 1 & & 2 & & 2 \\
\hline 8 & Farmers and fishermen & & 3 & 7 & 50 & 3 & & 12 \\
\hline 9 & Lower-skilled workers & & & 1 & & 1 & & \\
\hline & Unskilled workers & & & & & & 0 & \\
\hline $10+12$ & Farm workers & & & 1 & 7 & 2 & & 10 \\
\hline
\end{tabular}

Table 8. Socio-professional status of husbands' fathers, compared with that of their in-laws: third-generation cohort (the grandsons of the I20 couples in the sample, who married after I860)

\begin{tabular}{|c|c|c|c|c|c|c|c|c|}
\hline \multicolumn{2}{|c|}{$\begin{array}{l}\text { Status of husbands' fathers (down) and } \\
\text { in-laws (across), by category }\end{array}$} & \multirow{2}{*}{$\begin{array}{r}1+2 \\
0\end{array}$} & \multirow[t]{2}{*}{$3,4,5$} & \multirow[t]{2}{*}{$6+7$} & \multirow[t]{2}{*}{8} & \multirow[t]{2}{*}{9} & \multirow[t]{2}{*}{11} & \multirow[t]{2}{*}{$10+12$} \\
\hline $1+2$ & $\begin{array}{l}\text { Higher managers and } \\
\text { professionals }\end{array}$ & & & & & & & \\
\hline $3,4,5$ & $\begin{array}{l}\text { Lower managers and } \\
\text { professionals, clerical and sales }\end{array}$ & & 0 & & & & & \\
\hline $6+7$ & Skilled workers & & & 0 & 4 & & 1 & 1 \\
\hline 8 & Farmers and fishermen & & & & 42 & & 5 & 5 \\
\hline 9 & Lower-skilled workers & & & & 2 & 0 & 1 & 1 \\
\hline & Unskilled workers & & & & & 1 & 0 & 1 \\
\hline $10+12$ & Farm workers & & & & 6 & 3 & 1 & 16 \\
\hline
\end{tabular}

similar, marrying the heir or heiress to a farmhouse or other business of comparable size and status in the village or nearby. These were the men or women who received compensation for their legal shares of the inheritance (equal to the préciput share, or 25 per cent of the assets ${ }^{20}$ ), and used it as a dowry to marry into propertied families of the same status. ${ }^{2 \mathrm{I}}$ Thus, all

Duroux, "Emigration, Gender, and Inheritance. A Case Study of the High Auvergne, I7001900", in Green and Owens, Family Welfare, pp. 47-72.

20. To marry within their social group, men and women had to present a dowry equivalent to the préciput (equal to 25 per cent of the assets) or the extra share which the heir or heiress received upon marriage. If they were unable to save for such a dowry (as a result of the family being large), they could not marry within their social group.

2I. The inheritance strategies to secure single inheritance were complex. They aimed at maintaining the house and property intact from one generation to the next while providing the non-inheriting siblings with compensation (generally less than their equal share) so that they 
Table 9. Socio-professional status of wives' fathers, compared with that of their in-laws: third-generation cohort (the granddanghters of the 120 couples in the sample, who married after I860)

\begin{tabular}{|c|c|c|c|c|c|c|c|c|}
\hline \multicolumn{2}{|c|}{$\begin{array}{l}\text { Status of wives' fathers (down) and in- } \\
\text { laws (across), by category }\end{array}$} & \multirow{2}{*}{$\begin{array}{r}1+2 \\
1\end{array}$} & \multirow{2}{*}{$\begin{array}{r}3,4,5 \\
1\end{array}$} & \multirow[t]{2}{*}{$6+7$} & \multirow{2}{*}{$\begin{array}{r}8 \\
1\end{array}$} & \multirow[t]{2}{*}{9} & \multirow[t]{2}{*}{11} & \multirow[t]{2}{*}{$10+12$} \\
\hline $1+2$ & $\begin{array}{l}\text { Higher managers and } \\
\text { professionals }\end{array}$ & & & & & & & \\
\hline $3,4,5$ & $\begin{array}{l}\text { Lower managers and } \\
\text { professionals, clerical and sales }\end{array}$ & & 0 & 1 & 1 & 1 & & \\
\hline $6+7$ & Skilled workers & & 2 & 4 & 1 & & & 1 \\
\hline 8 & Farmers and fishermen & 1 & 1 & & 70 & 1 & & 15 \\
\hline 9 & Lower-skilled workers & & & 1 & 1 & 2 & & \\
\hline & Unskilled workers & & & & & & 0 & \\
\hline $10+12$ & Farm workers & & & & 6 & 6 & & 14 \\
\hline
\end{tabular}

heirs and their spouses generally married men and women of similar socioprofessional backgrounds. These homogamous marriage practices ensured continuity of property transmission (single inheritance) and family traditions, as well as stable social mobility for heirs, heiresses and their spouses in their rural environment.

Many children from landless families (categories 9 to I 2) also married within their own socio-professional group. These men and women, whose parents were landless farmers, landless artisan farmers or landless artisans, married individuals whose parents had the same socio-professional backgrounds (see Tables 5 to 9). ${ }^{22}$ They were engaged in the same profession as their parents and enjoyed the same status in their village of birth or nearby. Through these homogamous marriages they were assured of mutual help and family assistance in the environment they grew up in. We may thus conclude that marriage strategies among Basque rural families, whether propertied or landless, remained homogamous for the large majority of their descendants throughout the nineteenth century, and that couples experienced stable intragenerational and intergenerational social mobility.

could be comfortably settled and would not demand their equal share of the inheritance (this would have forced the estate to be partitioned). In this manner, the heir or heiress inherited the entire property, and one or two siblings generally received compensation for their share of the inheritance upon leaving the family house (generally in their youth, before their parents' death); this compensation they then used to marry into a propertied family or to emigrate to cities or overseas. The others remained single (at home or in the village, in towns or cities), never daring to force a partition of the estate to obtain their legal shares. All, however, enjoyed family solidarity. To survive, the system sometimes required family cohesion and individual self-denial.

22. Unlike propertied families, landless families rarely lived as stem families. Their rented farms were too small to house and occupy extended families. They often lived close to one another (as neighbours), but as nuclear families. Hence Peter Laslett's conclusions on the high frequency of simple households since the modern era. 
When comparing the behaviour of men and women, however, we observe some gender differences. It appears that among the men and women of the second-generation cohort particularly, women had greater difficulty marrying within their socio-professional group (see Tables 3 and 4, p. IOI). Though women from propertied families inherited the family's assets more often than men, or married heirs within their own socioprofessional group, and women from landless families generally married landless men originating from landless families, homogamy was less prevalent among women than among men. Why? Why did more women marry men whose parents had different socio-professional backgrounds? Did women's parents have a higher or lower status than their in-laws? The analysis of marrying upward and downward will perhaps explain gender differences in migration destinies.

\section{MARRYING INTO FAMILIES OF HIGHER STATUS} (UPWARD MARRIAGES)

The data indicate that some men and women in the sample did indeed marry outside their socio-professional group, yet few among the first-, second-, and third-generation cohorts married men or women whose parents enjoyed a higher status than their own parents. Furthermore, in the course of the century it became difficult for women to marry into higherstatus families. The data clearly show that, proportionally and over time, both men and women had less chance of marrying a person from a wealthier background: the figure for women was i 8. I per cent in the early nineteenth century (first-generation cohort), 20.6 per cent in the midnineteenth century (second-generation cohort), and $\mathrm{I} 3.6$ per cent in the late nineteenth century (third-generation cohort); for men it was I6.2 per cent, I 4.3 per cent, and I 4.4 per cent respectively (first-, second-, and third-generation cohorts) (see Tables 3 and 4 ). Why did women experience greater difficulty in marrying upward than men?

The men who were able to marry into a wealthier family were the sons of propertied farmers, artisan farmers or artisans (categories 7 and 8) who, through hard work and thrift, married the heiresses of these wealthier families (see Tables 5 to 9). Capable of amassing large savings, especially after a few years spent in America, they also amassed a sizeable dowry which allowed them to marry into a wealthier propertied family and move up the social ladder. Some men married the non-inheriting daughters of these wealthier families, before emigrating to America or purchasing a property locally. Though these cases were very few, it seemed easier for hard-working men to marry upward than for hard-working women, men being able to save a greater amount of money than women and being in a better position to bargain their way into a wealthier family.

By contrast, the daughters of propertied families (categories 7 and 8) 
experienced greater difficulty in marrying into wealthier families in the second half of the nineteenth century (third-generation cohort) because the job market and their lower level of education made it more difficult for them to find good jobs, to save a large amount of money, to amass a larger dowry than the préciput share, and to marry heirs of wealthier propertied families. As a result, some emigrated to cities, where they sometimes married into wealthier families - their husbands being merchants, professionals, or civil servants (higher or lower ones) (categories I to 5). These women were very few in number though, and became even fewer in the second half of the century (see Table 4, p. IOI). Marriage opportunities were definitely not so favourable for women as for men.

Many men from less affluent backgrounds, whose parents were landless farmers, artisan farmers, artisans, or even unskilled workers (farmhands or artisan workers), (categories 9 to I 2 ) could also improve their life and status through hard work and thrift, using their savings as dowries to marry into local propertied families (categories 7 and 8). They became farmers, artisan farmers, or artisans, all owning a house with a small or modest property in the course of their lives. By contrast, women from poorer backgrounds (daughters of landless families) could hardly ever marry upward into wealthier families in their rural environment because, as was the case for the daughters of propertied families, the job market and their lower level of education left them with no access to better-paid jobs. Consequently, they could not save enough to amass a dowry and marry a propertied man. The only instances when they could marry into a propertied family were if a widower remarried, when the heir's wife or the heiress of a farm or business died young. They then assumed the responsibilities of the late wife or heiress, taking care of the husband's young children (their stepchildren) until the next succession. In no other situation could the daughters of landless families marry upward.

The data conclusively indicate that the men in the sample were more conservative than the women, since the men remained more attached than the women to land, property ownership, and to rural life in the Basque country or in America. They saw marriage as a means of preserving or improving their lifestyles in their rural environment or abroad, and of ensuring the continuity of their traditional family practices. ${ }^{23}$ The women, by contrast, seemed more emancipated, attached to status and property ownership, but far less to farm life and to their rural environment. When they could not marry into their socio-professional group, they sacrificed their lifestyles and environment to live more comfortable lives in cities,

23. Men valued their rural environment and their lifestyles as propertied farmers or mediumskilled workers. When they could not secure such a lifestyle in their rural environment, they emigrated to America, where they believed they had a greater chance of improving their lives than in cities, and where they could reproduce their family's lifestyle. For comparison, see Lorenzetti, Head-König, and Goy, Marchés, migrations et logiques familiales. 
perhaps with men from higher social backgrounds, and in the process they were forced to break their ties with the family environment and with family traditions and practices. ${ }^{24}$ As the following will show, explanations for the different marriage strategies of men and women will emerge more strikingly from the analysis of downward marriages. As a result of these observations, it will soon become clear that marriage opportunities had a great impact on the decisions of men and women in relation to rural, urban, or overseas migration.

\section{MARRYING INTO FAMILIES OF LOWER STATUS (DOWNWARD MARRIAGES)}

Through the century, many of the men and women of the second- and third-generation cohorts did marry into lower-status families (see Tables 3 and 4). These were particularly the granddaughters of the I 20 couples; the parents of these granddaughters were higher or lower professionals, managers, or civil servants (categories I and 5) who had returned to agricultural labour or craft professions as property owners. They had married men and women from lower social backgrounds, especially the heirs or heiresses of propertied farmers, artisan farmers or artisans (categories 7 and 8), or landless artisans (category 9) (see Table 9, p. I04). However, these individuals were very few. They seemed to value rural life and their ancestral family environment more than status and social mobility.

Women who married men of lower status were sometimes heiresses whose parents valued the importance of the dowry rather than status. These families therefore preferred their heiresses to marry hardworking, thrifty men who, though from a lower social background, could amass a sizeable dowry and bring it into the marriage. As many non-inheriting sons often emigrated to America, the family seemed to resort to marrying off their heiresses to men from lower social backgrounds, men who brought a cash dowry into the house and showed submission.

The large majority of those who married down, however, were the noninheriting children of propertied farmers, propertied artisan farmers or propertied artisans (categories 7 and 8), especially women who, among their numerous siblings, did not inherit a sufficient share of the inheritance (less than 25 per cent of the family's assets) and who therefore did not manage to marry into a propertied farming or artisan family of equal social status. They were individuals who were engaged in the professional activities of their parents as farmers, artisan farmers, or artisans, yet were

24. Recent comparative works on migration are numerous. See particularly Frans van Poppel, Michel Oris, and James Lee (eds), The Road to Independence: Leaving Home in Western and Eastern Societies, I6th-20th centuries (Berne, 2004). 
unable to own the land they worked on or the business in which they worked. Most of them therefore became very small propertied or landless farmers, artisan farmers or artisans, and married landless sons and daughters of lower status. Thus, their marriages were downward not necessarily as a result of their different professional activities (parents and in-laws actually engaged in the same professions), but instead due to the lower social status of their in-laws as landless farmers, artisan farmers, or artisans in the community or nearby.

When comparing the marriage strategies of men and women, however, we observe that in the course of the century more women, especially heiresses and non-inheriting daughters from propertied families, married outside their social group and with men of lower status. They made up the large majority of those who accepted downward marriages, the men often preferring emigration to America instead. They were heiresses who married men of lower status - the sons of landless farmers, artisan farmers, and artisans who through hard work and thrift amassed sizable dowries. They were also non-inheriting daughters of propertied families who received small dowries (if at all), too small to marry heirs (even minor ones) and who refused to emigrate to America with their brothers. In that case, they opted for marriages with landless farmers or lower-skilled artisan workers, who might have been engaged in the same profession as their parents but who originated from families of lower social status, managing sometimes to acquire property in the course of their lives but not to the point of reaching their parents' status. All cases considered, it appears that on average I7.5 per cent of Basque women married downward in the nineteenth century (compared with is per cent of men).

The data thus indicate that in the course of the century there were indeed inequalities between the marital strategies of men and women, men generally marrying within their socio-professional group or upward while women more often married within their socio-professional group or downward (see Tables 3 and 4 , p. I०I). In an attempt to avoid downward marriages and downward social mobility, the sons of propertied families emigrated to America and daughters to cities. When emigrating to America, they generally maintained or improved their lives, some having more traditional behaviour as they lived in a familiar, rural environment which siblings and/or uncles had reconstituted, reproducing the family's lifestyle and practices. When settling in cities, women opted for emancipation, preferring to marry civil servants in cities, men of higher social status from elsewhere in France who offered them better lives, but away from their rural environment. ${ }^{25}$ In the

25. Pierre Bourdieu also argued that women were more emancipated than men, adopting modern attitudes more rapidly than men in their quest for a better and easier life, especially in towns or cities; Pierre Bourdieu, Le bal des célibataires. Crise de la société paysanne en Béarn (Paris, 2002). 
process, these women accepted having to break with their family, traditions, and practices. ${ }^{26}$

Most sons and daughters of landless families married men or women within their own socio-professional group and were engaged in the same professions as their parents and in-laws. They consequently maintained their status as farmers, artisan farmers, or artisan workers, renting a house and land. While the great majority of these men and women thus experienced stable social mobility, a few married upward, especially men who married heiresses, and others married downward, especially women who married sons of unskilled workers or farmhands. These men and women, however, were few. As the following will show, the sons and daughters of landless families had a greater chance of marrying homogamously or upwardly than the sons and daughters of propertied families. How did marriage patterns affect migration patterns within propertied and landless families?

\section{HETEROGAMY AS AN EXPLANATION FOR EMIGRATION}

The quantitative analysis of the data yielded rich findings and was helpful statistically to draw important conclusions on Basque marriage strategies in the nineteenth century. But a combined analysis of the computerized quantitative data with the qualitative observation of the genealogies will lead to an even more refined argumentation and further inferences. The conclusions will here draw our attention to the significance of marriage strategies in securing ancient single-inheritance practices. They will also give a more complete picture of the mechanisms which led men and women within the same family to have different marriage strategies. Finally, they will explain why men from all social backgrounds married upward more often than women, and what implications these situations had for migration, from a family perspective. The conclusions will differ depending on the socio-economic background of the families. We will consider propertied families first, and then non-propertied families.

The data and the genealogies clearly highlight the fact that as family size grew in the course of the nineteenth century it became more difficult for Basque propertied families (farmers, artisan farmers, artisans) to secure homogamous marriages and socio-economic stability for all of their children. They had no problem settling two or three of their children, marrying them off within their own social group - one as the heir or heiress of the family house or business, marrying the non-inheriting child of a propertied family, and one or two marrying heirs or heiresses. It was

26. For a comparative study on family in the age of urbanization, see Gerard Bouchard and Joseph Goy (eds), Famille, économie et société rurale en contexte d'urbanisation (XVIIe-XXe siècles) (Paris, I990). 
impossible, however, to settle all the children comfortably, especially when there were more than three; hence the high celibacy rate among the children of these families, men and women equally (I 9.7 per cent among the second-generation cohort and 19 per cent among the third-generation cohort).

To avoid treating sons and daughters unequally and discriminating against daughters with regard to marriage and inheritance, propertied families often selected their daughters as heiresses or married them into propertied families. ${ }^{27}$ Women were considered suitable successors to and transmitters of traditions and property, even if they had brothers (whether older or younger). They were perhaps more submissive and more flexible, sometimes accepting undesirable conditions which their brothers refused; they might well, for instance, be prepared to marry the sons of landless farmers, artisan farmers, or artisans who had saved a lot of money.

Despite the favourable treatment of propertied families towards women, men had a greater chance of marrying within their socio-professional group or upward and of experiencing stable or upward social mobility. They sometimes preferred to receive a dowry which, added to their personal savings (from America sometimes), allowed them to marry upward into wealthier propertied families, and sometimes of becoming coowners of a larger property. Indeed, whenever possible, men (even firstborn sons) relinquished their inheritance rights as potential heirs, marrying the heiresses of richer families (farmers or artisan farmers), using their dowries to purchase the shares of the inheritance of the siblings of the heiress and thus gain power and respectability within the wealthier houses of their in-laws. When this option was not available, they instead emigrated to America, where they generally fared well as unmarried men. They thus enjoyed greater freedom of choice and movement than women, avoiding homogamous marriages at home under their parents' authority, as well as downward marriages into the lower-status families of landless farmers, artisan farmers, or artisans.

Non-inheriting children seemed to opt for celibacy rather than downward marriages, for three main reasons: because they could not engage in the same activity as their parents, in the same familiar environment; because they could not marry within their own socio-professional group; and because marriage did not guarantee them the same social status as that of their parents. At times, women from propertied families accepted marrying down and out of their parents' social group; but men did so more rarely. Indeed, the data indicate that among the second- and third-

27. This was also the case in other parts of the Pyrenees: in Béarn, as Jacques Poumarède and Christine Lacanette-Pommel have noted; in the Baronnies, as Rolande Bonnain has shown; and in Esparros, as Antoinette Fauve-Chamoux has explained. On the matter of inheritance strategies in a comparative perspective see Fauve-Chamoux and Ochiai, Maison et famille souche. 
generation cohorts nineteen and seventeen daughters respectively from propertied families married downward, their in-laws enjoying a lower social status than their parents - being engaged in the same professions, but as landless farmers, artisan farmers or artisans (see Tables 7 and 9). By contrast, the same was true of only five propertied families' secondgeneration sons and six propertied families' third-generation sons (see Tables 6 and 8).

Men definitely refused downward marriages. Instead, they remained single in the village or emigrated to America where, as early as the midnineteenth century, they were engaged in either the same professions as their parents or better (as propertied cattle raisers, farmers, artisans, or professionals), often refusing marriage altogether in order to be able to return to their village of birth on retirement. Conversely, women did not emigrate in such frequent numbers, nor so early on in the century. If they could not inherit the family property or marry into a propertied family, they had two options it seems: downward marriage in their familiar rural environment, or celibacy in the village or nearby, in towns, or in cities. Only in the second half of the century did many of them envision exogamous marriages with men originating from wealthier families in cities, or homogamous marriages, perhaps before departing overseas.

Consequently, a great number of men were bound to marry into wealthier families than their sisters, and few married into lower-status families. Rather than accept downward marriages, they emigrated to America. Women for their part had fewer options available. If they could not inherit or marry into a propertied family of equal status (homogamous marriages with stable social mobility), which a great number of them did, their best chance to marry upward was by marrying the son of a higher or lower professional, of a manager or a civil servant in local towns or in cities. Emigration to America was a safe destination for the daughters of propertied families when they married men within their own social group before departure, each receiving a dowry to finance their fare to America and their settlement. They were, however, reluctant to settle in America permanently, perhaps because they considered life in La Pampa (Argentina) for example to be too hard and insecure. Clearly, marriage opportunities in the Basque country were not so favourable for women. This perhaps explains the higher celibacy rate of women throughout the century; celibacy was the only way to avoid downward marriage in the village or nearby, or homogamous marriages as housewives in America.

The sons and daughters of propertied families sometimes avoided marriage altogether in order to maintain their rights over the family assets, having the option of living and dying or returning to the family house on retirement. As they generally received no compensation for their shares of the inheritance before their departure from the family house, they remained co-owners of the family assets, maintaining in the process their 
status in the village as the sons and daughters of property owners. Before they died, they would donate their shares of the inheritance to the heir or heiress of the house. ${ }^{28}$ Heirs or heiresses appreciated the sacrifice of their unmarried siblings because it meant that they need not provide additional dowries for them. In this manner, the family house and land remained intact through the century and was transmitted undivided to the next generation, despite the egalitarian laws of the Civil Code.

To illustrate the above arguments in relation to the marriage strategies of propertied families, we will use the example of the M. family from Sare (see family tree: case study I). Martin M. and Magdeleine from Sare (firstgeneration cohort) married in I 802. Magdeleine inherited the I7-hectare property from her parents and Martin (the son of a propertied family who owned I 2 hectares) brought a I,000-franc dowry into the marriage. Their marriage was homogamous, both Martin and Magdeleine originating from the same village and marrying within their socio-professional group. Further, both were engaged in the same profession as their respective parents, and enjoyed the same status as those parents. As the family was relatively small, the couple managed to settle all three children equally comfortably, within their social group but sometimes outside their professional environment (second-generation cohort). However, all of them experienced stable social mobility during their lives.

Jean, the first-born son (second-generation cohort), inherited the family assets (the house and I 2 hectares of land) when, in I 830, he married Marie D., born in Sare and the daughter of a propertied farmer who owned a house and 9 hectares of land. Marie brought a dowry of I,०00 francs to compensate at least one of Jean's siblings. Like their respective parents, Jean and Marie married within their socio-professional group, their marriage being as homogamous as their parents'. Jean-Etienne, the second-born son, was compensated for his share of the inheritance when, in 1854 , he married Marianne B., born in Sare and the daughter of a local propertied farmer. After their marriage, they emigrated to America. Like their parents, they married within their socio-professional group (homogamy), but they had different destinies in America. Marie, the third-born daughter, was also compensated upon her marriage, in 1844 , to JeanBaptiste D., an urban propertied shoemaker, the son of a propertied shoemaker from the city of Bayonne. They too later emigrated to America.

28. This right was termed the "droit de chaise". It was derived from ancient family rights and, according to pre-revolutionary customs, entitled all unmarried siblings, men or women, who did not receive a dowry, to live and die in the family house. Though deprived of compensation which would otherwise have enabled them to marry decently into a propertied family, these men and women could enjoy a decent life with the heir or heiress until death. This was a way to avoid providing additional dowries which might burden the family financially, to limit land partition, and, consequently, to maintain the family assets (the house system, earlier explained) intact from one generation to the next, despite the egalitarian laws of the Civil Code. 


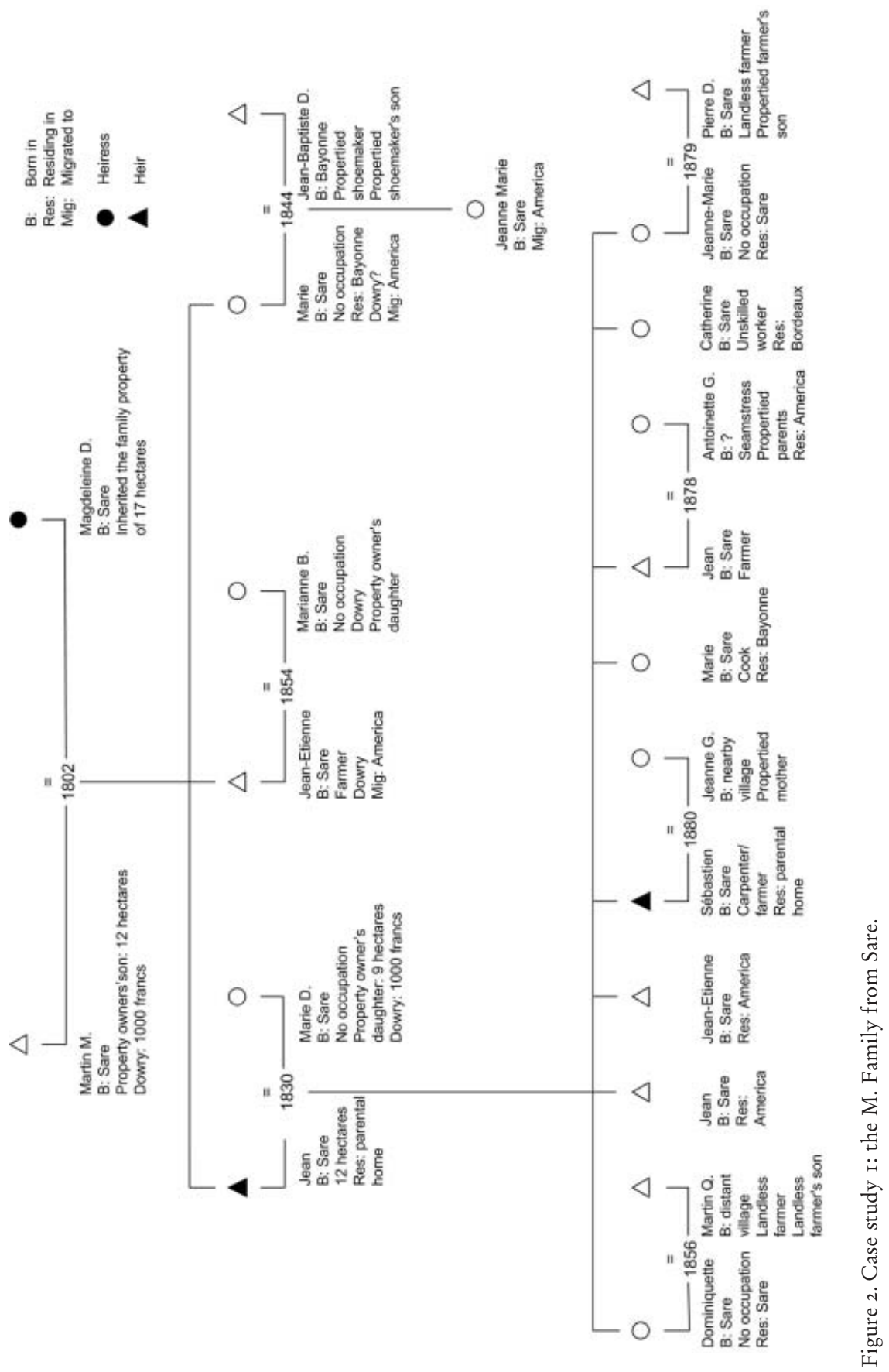


Marie's marriage was not particularly homogamous, unlike her brother's. Though she married within the social environment of her parents, she did not marry within their professional environment.

One may conclude that as a result of this moderate family size the children were able to marry into propertied families (farmers, artisan farmers or artisans), each child receiving a decent dowry (worth 25 per cent of the family's assets), enough to marry a person of equal social status (homogamy). Though the three children had different destinies in the village (for Jean), in America (for Jean-Etienne), and in the city of Bayonne and later in America (for Marie), they all enjoyed the same social status as their parents.

In the next generation (third-generation cohort), marriage strategies evolved considerably as a result of Jean's larger family. Indeed, Jean (the first-born son above) had eight children. Given the large number of children to settle, it was difficult to marry off all eight of them comfortably. While in the previous generation, each child received a dowry worth 25 per cent of the assets (enough to marry within their socioprofessional group), Jean's children were each legally entitled to just 9.4 per cent of the assets, which was not enough to marry within their social group.

Following our earlier arguments on large families, this third-generation case study will demonstrate that the men did indeed do better than the women, Jean's sons marrying into propertied families (Sébastien, his fourth-born son, and Jean, his sixth-born son) or emigrating to America (Jean, his second-born son, and Jean-Etienne, his third-born son), probably to avoid downward marriages, while his daughters sometimes married into lower-status families - Dominiquette (his first-born daughter) for instance married a landless farmer's son (Martin Q., from a distant village). The marriage of Jeanne-Marie (Jean's eighth-born daughter) was as homogamous, though, as her brothers' because she married the son (Pierre D. from Sare) of a propertied farmer. Nonetheless, she experienced downward social mobility since her husband became a landless farmer. The other daughters finally remained single in cities, probably to avoid downward marriages.

Thus, among Jean's four married children, three (one son and two daughters) married within the family's socio-professional group, and one (a daughter) married downward. Though homogamy remained prevalent, it did not secure stable social mobility - two of Jean's married daughters (Dominiquette and Jeanne-Marie) experiencing downward social mobility, their husbands being landless farmers. These marriage strategies, however, allowed them to settle in the village, in their familiar rural environment, avoiding celibacy and emigration. It was probably to avoid downward marriages and downward social mobility or because they were unable to make homogamous marriages with the sons of propertied 
families at home that Jean's two unmarried daughters (Marie and Catherine) probably migrated to the regional cities of Bayonne and Bordeaux respectively, where they died unmarried.

The only one to make a homogamous marriage and to enjoy stable social mobility was the heir, Sébastien, Jean's fourth-born son, who married the daughter of a propertied family and inherited the family property, enjoying the same status as his parents and in-laws. It was probably a privilege for him to inherit, yet he had to wait until i 880 before he could marry, by which time all his siblings had married and departed. His brothers, though, refused to marry either late or downward (probably for various reasons). They, therefore, accepted modest compensation in advance of their succession in order to emigrate to America as single men (as Jean, the second-born son, and Jean-Etienne, the third-born son, did) or as married men: Jean, the sixth-born son, married within his parents' socio-professional group (a homogamous marriage) before departing. In the case of large families, it was more difficult for parents to marry each child into a propertied family and to secure for them stable social mobility. Women seemed to pay the price for this, more of them either accepting downward marriages and experiencing downward social mobility or resorting to celibacy.

This case study clearly shows that, in the matter of marriage strategies and social mobility, women did not do so well as their brothers. Some opted for downward marriage strategies, marrying men of lower socioprofessional backgrounds and enjoying a lower status in order to settle in their familiar rural environment. Others, though, opted for celibacy, refusing downward marriages and downward social mobility. Thanks to their sacrifice, single inheritance and the full transmission of the house and land to one child prevailed and family lineage and succession were thus secured.

Paradoxically, conditions with regard to marriage strategies were sometimes better for sharecroppers' children, especially men. The historiography argues that these families were so poor and the economic possibilities so limited that they could not survive in the village and therefore had to emigrate in order to secure themselves a decent life. This explains why, according to some historians, emigration affected the lower strata of rural society more than the higher strata. Yet the data on Basque families in the nineteenth century show a different picture. The great majority of the children of landless farmers, artisan farmers, and artisans managed to settle in their village of birth or nearby. They were very mobile, but only locally, moving perhaps within a few miles of their village of birth, where most of their relatives lived as well. It was a strategy to secure mutual assistance and family solidarity.

One may argue that they were too poor to afford emigration and that they lived within a familiar professional and geographical environment out 
of necessity and survival. They actually had new opportunities, especially the men. Their massive, permanent emigration took place only late in the century and they did not seem to be attracted to cities at all, but to America instead. We did locate some of them in local towns (towns near their village of birth), but hardly any in distant coastal towns and regional cities. Why did so many of them decide to settle in the rural environment, even after emigration agents had begun recruiting potential candidates for overseas settlement in I 860 ? And what were their marriage strategies and their destinies?

While some may argue that the majority of the sons and daughters of landless farmers, artisan farmers, and artisans had survival behaviours, all marrying within their familiar environment, their professional network, and their social group, the data sometimes provide material for a different interpretation. The large majority of them did indeed have homogamous behaviour as they married within their socio-professional group: men and women whose parents were engaged in the same professions and enjoyed the same status. Yet some had new possibilities for upward marriage and upward social mobility in their familiar rural environment. Most of them were men who filled the positions left behind by the sons of propertied families who did not inherit in order to marry an heiress, or emigrate to America, or remained single instead. Indeed, the sons of many propertied families relinquished their inheritance rights as heirs to marry out or upward, or else emigrate to America.

As a consequence, propertied families sometimes had difficulty finding sons-in-law within their social group in the village or nearby. As a replacement, they welcomed the sons of landless families into their house, men who were submissive, hardworking, and thrifty, capable of saving large sums of money and therefore of bringing a decent cash dowry into the marriage. The sons of these landless families (whether they were farmers, artisan farmers, or artisans) thus successfully married into propertied families. They avoided cities or emigration to America, not so much because they were too poor, but because they sometimes had an opportunity to improve their lives through upward marriages with heiresses in the village or nearby, or as propertied artisans. Only in the latter part of the century did they emigrate to America, emigration agents largely contributing to their massive departure by offering employment opportunities with a greater chance of upward social mobility than in the village. There were then fewer sons and daughters from landless families to marry in their villages or nearby.

Conversely, the daughters of landless families, who had difficulty amassing a dowry despite hard work and saving, hardly ever married upward in the village or nearby. They generally maintained their status by marrying the sons of landless farmers, artisan farmers, or artisans. These homogamous marriage strategies were vital, however, for their survival. 
They rarely remained single, celibacy only securing them an even poorer and more insecure life as unskilled workers (servants) and therefore downward social mobility at mere subsistence levels. The conditions for women from landless families were therefore very hard, harder than for the men of their social group and also harder than for the women of higher social groups. For women from landless families, marriage was vital if they were to live a life above subsistence level.

A few women, however, improved their lot through upward marriage, occasionally marrying into propertied families, but only to widowers in order to take care of their husbands' underage children until the succession of the next generation. As time went by, though, the number of daughters of landless families available for marriage within their socio-professional group in their village of birth or nearby became fewer. Instead, they reverted to massive overseas emigration in the latter part of the century, especially as families, appealing to emigration agents to reunify them with their families and hopefully secure upward social mobility for them in America.

To illustrate the above arguments in relation to the marriage strategies of landless families, we shall look at the U. family from Aldudes (see family tree: case study 2, overleaf). Jean U and Marthe (first-generation cohort) married in Aldudes, their village of birth, in I808. Both married within their social group (homogamy), their parents enjoying a higher status as propertied farmers. As the young couple had an illegitimate child, they were not entitled to inherit. As a consequence, they became landless farmers in Aldudes and experienced downward social mobility. Like their respective parents, they were farmers in the village, yet enjoyed a lower social status. Together, they had six surviving children, all born in Aldudes (second-generation cohort). As a result of their marriage strategies and the assistance of their families, none of them married downward and none of them experienced downward social mobility. They married within their own social group (homogamy) (marrying the sons or daughters of landless families) or upward (marrying the sons or daughters of propertied families). In the process, they either maintained their status as landless farmers, artisan farmers, or artisans in the village or nearby, or actually improved it as propertied farmers, artisan farmers, or artisans.

Guillaume, the first-born illegitimate son, experienced upward social mobility since he became a professional soldier in Bayonne, the regional capital. However, as a result of his illegitimacy perhaps, he remained single. Jean, the second-born son, married into two local landless families in the village since he married, successively, two sharecroppers' daughters, Catherine O. and Jeanne P., in I 852 and I 860 respectively. Finally, in I 859 , Michel, Jean's sixth-born son, married Jeanne I., the daughter of a propertied farmer from Aldudes. His marriage was upward. He later experienced upward social mobility, settling as a property owner in the 


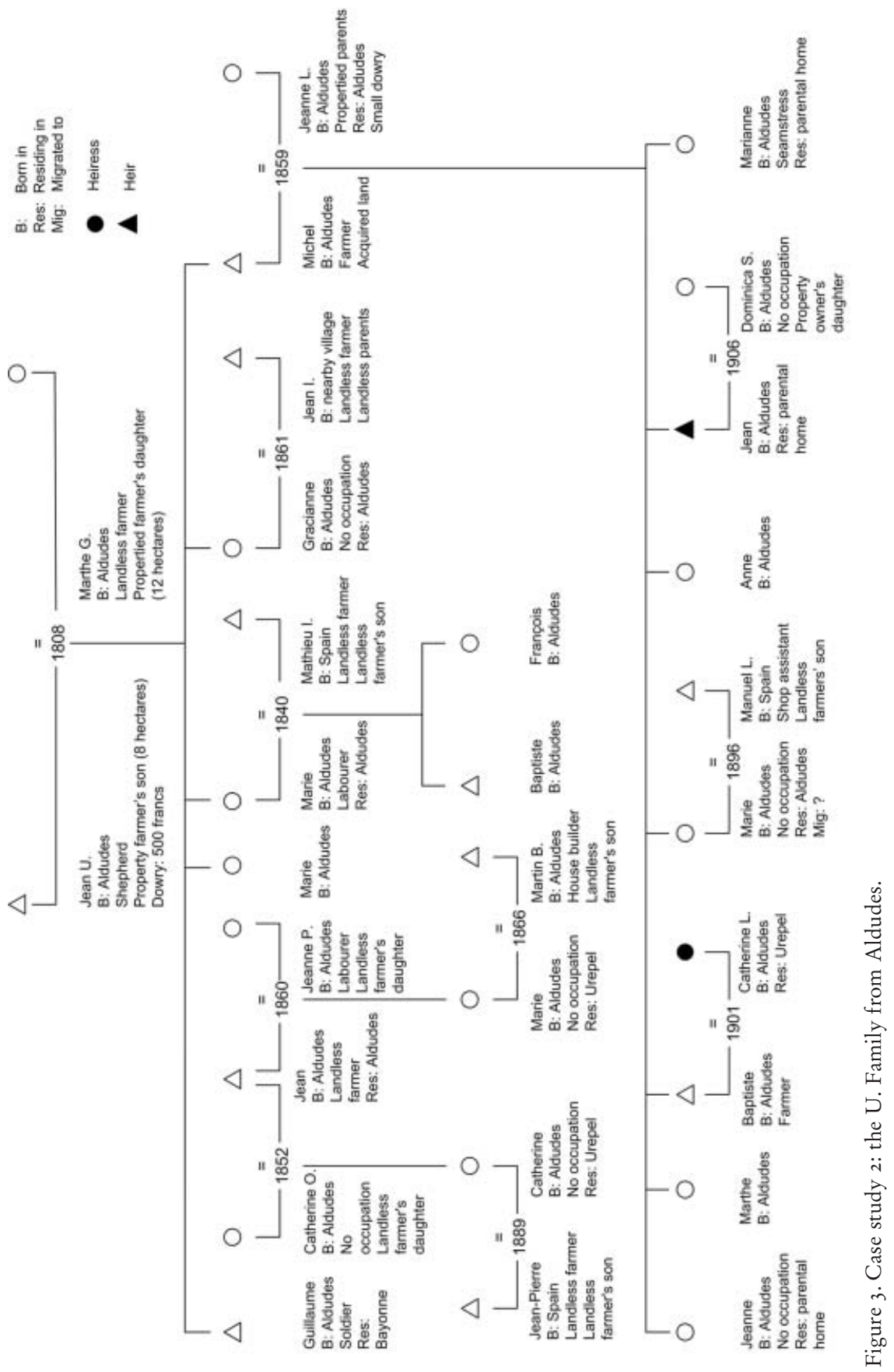


village. Hence, the men of this family did relatively well, marrying within their social group or upward, and maintaining or improving their livelihood.

The women of the family, by contrast, did not do so well, all marrying sons of landless farmers. They thus maintained their status but did not improve it. No information was found on Marie, Jean's third-born daughter. However, Marie, his fourth-born daughter, married Mathieu I., the son of a landless farmer from Spain, in the village in 1840 . Their marriage strategy was homogamous as both were born into landless families, were engaged in the same profession as their respective parents (as farmers), and enjoyed the same status (as a landless couple). Finally, the experience of Gracianne, the fifth-born daughter, was similar. In I 86 I she married Jean I., the son of a landless farmer, born in a neighbouring village. Both married into families with the same socio-professional background, and both experienced stable social mobility. This landless family obviously had priorities: to settle their daughters within their socio-professional environment and help them to maintain their status and lifestyle as landless farmers in the village or nearby so that, through family solidarity, they did not experience downward social mobility and poverty.

In the next generation, Jean and Marthe's grandchildren (thirdgeneration cohort) did exactly the same, especially the granddaughters. Indeed, Jean (Jean's second-born son above), a landless farmer, had two daughters. Catherine, his first-born daughter (from his first marriage), married the son of a landless farmer in I889; Marie, his second-born daughter (from his second marriage), married a landless artisan worker (a house builder) in i 866; he himself was the son of a landless farmer. Both daughters married within their social group (homogamy). Yet Marie (the second-born daughter) had a different destiny, her husband being engaged in a different profession as a landless artisan. That was perhaps part of their strategy to maintain their lifestyle and their status in the village or nearby.

Michel (Jean's sixth-born son above), who had married into a wealthier family and acquired property using his savings and his wife's dowry, had seven surviving children. They had all been brought up as sons and daughters of property owners and probably wished to reproduce their father's marriage strategies, marrying into a propertied family and enjoying his status. Yet, as was typical of the marriage strategies of propertied families, men sometimes settled more comfortably than women. Indeed, while the men did as well as their parents, marrying into propertied families and enjoying the same status, women sometimes married downward, marrying men from landless families. Some therefore experienced downward social mobility. Michel's first-born and seventhborn daughters, Jeanne and Marianne, remained single in the family house, probably to avoid downward marriages or emigration. No information was found on Marthe and Anne, the second-born and fifth-born daughters 
respectively. However, the two sons did quite well, as Baptiste, the thirdborn son, married Catherine L., an heiress, in I90I, and Jean, the sixthborn son, inherited the family assets when he married Dominica S., the daughter of a propertied farmer, in I906. The latter had to marry late though, after his siblings had married and departed from the house.

Clearly, it was difficult being one of the numerous daughters of a propertied family, as they had a much greater likelihood of marrying downward and of experiencing downward social mobility than the daughters of landless families and men in general. Hence their preference for remaining celibate in the village, in the town, or in cities, or for emigrating. They perhaps opted for celibacy as a strategy to avoid a hard life as the wives of landless farmers or landless artisans, with no authority, no decision-making power, and, more importantly, no ownership power. Celibacy did not secure better living conditions and social status, but it did enable the daughters to maintain their family ties and status as the daughters of propertied families, and to maintain their freedom of movement, with the possibility of retiring in the village and perhaps in their family home, and later to donate their shares of the inheritance to the house's single heir. By contrast, celibacy was an option which the daughters of landless families did not consider.

\section{CONCLUSION}

Marriage strategies generally aimed at ensuring that men and women married within the family's socio-professional group and enjoyed the same status as their parents, avoiding downward social mobility whenever possible. However, marriage was also used more generally as a strategy to perpetuate family traditions and maintain harmonious family relations. The priority of propertied families was to transmit their property to one child from one generation to the next. They therefore had to make great efforts to settle all their children comfortably, especially when they had a large family. They made sure that the unequal treatment of children did not lead to family strife and forced partition. One may therefore argue that marriage strategies within propertied families aimed at securing ancient practices of single inheritance and at keeping family property intact, so that the family's roots and lineage could survive over time. For landless families marriage was also vital for survival. The large majority married within their socio-professional group, settled within fifteen miles, and avoided celibacy and cities whenever possible. The data and family reconstitutions clearly indicate that landless families were more successful than propertied families in ensuring their children married either within their socio-professional group or upward.

While the great majority of the men and women in the three cohorts managed, no matter their social and professional background, to reproduce 
their parents' behaviour through the nineteenth century, marrying within their socio-professional group (homogamy), engaging in the same profession, and enjoying the same status as their parents, children from propertied families, especially daughters, were increasingly unable to reproduce these patterns, and were forced to marry into landless families, becoming landless farmers, artisan farmers, or artisans in the village or nearby. A few - mostly men - did marry into wealthier families with similar professional backgrounds in the village. As a result, it was the daughters of propertied families who, in the course of the century, married into lower-status families and experienced downward social mobility; the daughters of landless families did better than the daughters of propertied families as they generally contracted homogamous marriages. Men, however, no matter their social background (propertied or landless), were more likely to do better than their sisters, entering into homogamous or upward marriages or remaining celibate and/or emigrating.

The economic situation of the rural Basque country was certainly not so favourable for the non-inheriting sons and daughters of propertied families, who were able to maintain their status through homogamous marriages, as heirs or heiresses, marrying non-inheriting sons or daughters, or as the spouses of heirs or heiresses, engaged in the same profession as their parents and enjoying the same status. Few acquired new properties, as land was scarce. Over time, fewer remained single at home. However, in all other cases men and women (mostly women in the village or nearby) married into lower-status families and experienced downward social mobility. Thus, when homogamy was impossible, and to avoid downward marriages, the sons and daughters of propertied families emigrated to America (in the case of men) or to cities (in the case of women), where they settled, married within their own socio-professional group or higher, or remained single.

Landless families had different marriage strategies. Not only were there great differences in marriage strategies between men and women, their marriage strategies and their destinies also differed from those of propertied families. The sons and daughters of landless families were highly mobile, but only locally, within a small territory (within a fifteen-mile radius of their village of birth), and they reproduced the homogamous marriage strategies of their parents. As the sons of propertied families emigrated to America, or used their savings to marry into wealthier families, they created scope for others to assume the responsibilities of the family business or farm, most notably their sisters, who inherited the family business and sometimes married the hardworking and thrifty sons of landless families; these sons became spouses to these heiresses and improved their status through marriage. The daughters of landless families, like the daughters of propertied families, had difficulty securing a decent lifestyle and status for themselves through marriage. They avoided 
celibacy and cities though, making efforts to marry the sons of landless farmers. They occasionally moved to local towns in order to secure a decent marriage. They used similar marriage strategies there, marrying the sons of landless farmers, artisan farmers, or artisans.

In the first half of the century America was not so much an option for the sons and daughters of landless families because they could not afford the passage and probably feared failing (with no possibility of returning home). In the second half of the century, however, many envisioned that destination, as single men or as families, with the help of emigration agents who recruited massive numbers of Basque emigrants in the countryside and organized their passage safely across the Atlantic.

To conclude, our study of marriage strategies among Basque propertied and landless families in the nineteenth century has highlighted the concern of all these families to ensure their children married within their socioprofessional group or better. Men, however, no matter their background, were more successful in this than women. Our study has also provided a better understanding of the migration destinies of men and women as a strategy to maintain family ties, secure mutual assistance, and perpetuate single inheritance. 